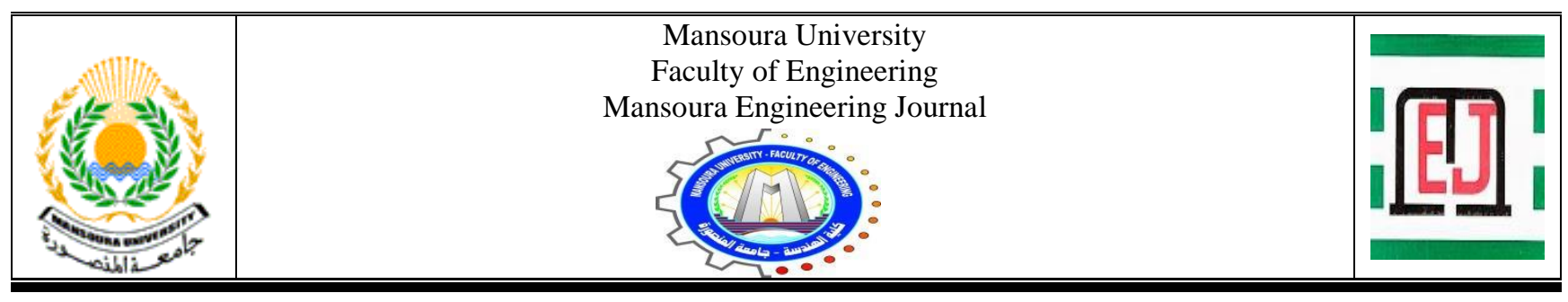

\title{
Comparative Study of Kinetic Hydrodynamic Theoretical Model Results in Fluidized Bed Reactor Using Different Fuels
}

\author{
A. S. El-Shafay, A. A. Hegazi, S. H. El-Emam, F. M. Okasha and E. S. B. Zeidan
}

\begin{tabular}{|l|}
\hline KEYWORDS: \\
Fluidized bed, Biomass, \\
Gasification, Syngas \\
\end{tabular}

\begin{abstract}
This work presents a comparative study on different biomass feedstock gasification in a fluidized bed using air. This work aims to study the effect of different biomass fuel types on the gasification performance in a fluidized bed, using kinetic hydrodynamic model results and similar experimental results. The feedstocks used in this study are sawdust pellets, Napier Grass, Portuguese Peach Stone, Chinese Coal /rice straw, solid waste wood, rice straw, and olive kernels. The theoretical results were obtained from the kinetic-hydrodynamic simulation of the fluidized bed. The theoretical results were compared with published experimental results. The results showed that the syngas contents are strongly affected by the gasification temperature, equivalence ratio, and fuel characteristics. Increasing ER increases the char burning rate to produce more $\mathrm{H}_{2}$ even medium equivalence ratio (usually less than 0.36 ) and decreases again. $\mathrm{CH}_{4}, \mathrm{CO}$, and $\mathrm{H}_{2}$ increased as temperature increased. From the fuel proximate analysis, the moisture contents affect the combustion reactions to generate more hydrogen. The lower $\mathrm{H} / \mathrm{C}$ ratio gives greater heating value, as well as gives more concentrations of $\mathrm{CO}$ and $\mathrm{CO}_{2}$. In the case of using waste woody and rice straw, the significant increase of carbon monoxide (from $9 \%$ to $19 \%$ ) and carbon dioxide (from $25 \%$ to $33.1 \%$ ) is due to a higher $\mathrm{C} / \mathrm{O}$ ratio in these biomasses analyses. The proximate analysis of feedstock and its contents from fixed carbons and volatiles matters affect strongly the producer gas concentrations, as a result, it's LHV. The maximum relative error between model results and experimental results within range $\pm \mathbf{1 0 . 2 \%}$.
\end{abstract}

Received: (11 October, 2020) - Revised: (18 January, 2021) - Accepted: (3 March, 2021)

Corresponding Author: A. S. El-Shafay is with Mechanical Power Engineering Department, Faculty of Engineering, Mansoura University, ElMansoura, Egypt (e-mail: seshabana@yahoo.com). https://orcid.org/00000002-7261-6686

E. S. B. Zeidan is with Mechanical Power Engineering Department, Faculty of Engineering, Mansoura University, El-Mansoura, Egypt (e-mail: ezeidan@mans.edu.eg).

S. H. El-Emam is with Mechanical Power Engineering Department, Faculty of Engineering, Mansoura University, El-Mansoura, Egypt (e-mail: sh_elemam@mans.edu.eg).

F. M. Okasha is with Mechanical Power Engineering Department, Faculty of Engineering, Mansoura University, El-Mansoura, Egypt (e-mail: faroukok@gmail.com)

\section{INTRODUCTION}

7 gasification process consists of drying, pyrolysis, combustion, and char gasification. The gasification process was performed using air and steam as gasifying agents. The gasifying agent types affect the product gas quality and its heating value. The composition of the syngas produced depends on the degree of equilibrium

A. A. Hegazi is with Mechanical Power Engineering Department, Faculty of Engineering, Mansoura University, El-Mansoura, Egypt (e-mail: ahmedabd_elsallam@yahoo.com). 
attained by various gas-phase reactions, especially water gas shift reaction, [1]. The biomass feedstock specifications have a major influence on the gasification process. The characteristics of biomass fuel were specified over the physical specifications, ultimate, and proximate analysis. The physical specifications contain all of the absolute density, particle size, and bulk density. The ultimate analysis contains oxygen, hydrogen, nitrogen, and sulfur. While a proximate analysis includes moisture content, heating value, and volatile matter, ash, and fixed carbon.

Li et al. [2] performed an experimental study on syngas production by co-gasification of coal and biomass in a fluidized bed. The authors found that the highest gasification efficiency is $60.92 \%$. Accordingly, the syngas yield and carbon conversions are $1.00 \mathrm{Nm}^{3} / \mathrm{kg}_{\mathrm{f}}$ and $88.89 \%$, respectively. Skoulou et al. [3] studied the olive kernels gasification in a fluidized bed reactor for $\mathrm{H}_{2}$ rich producer gas. Liu et al. [4] investigated the rice straw gasification in a fluidized bed gasifier using air. The performed temperature ranges are $600{ }^{\circ} \mathrm{C}$ to $800{ }^{\circ} \mathrm{C}$. The authors reported that the contents of combustible gas increased with temperature, an increase of oxygen concentration has a positive effect on gas quality and gasification result, but has a negative effect on gas yield. In addition, they stated that, when the temperature increase, $\mathrm{CO}, \mathrm{H}_{2}$ and $\mathrm{CH}_{4}$ contents in syngas increased at average level of $0.01 \%, 5.48 \%$, and $0.51 \%$.

Begum et al. [5] performed an experimental and numerical investigation of fluidized bed gasification of solid waste. An aspen plus simulation model was developed based on the experimental setup and findings. The simulation model was validated by the experimental results of a pilot-scale SW gasification plant. The authors stated that a good agreement was found between simulation and experimental results, with a maximum error of $\pm 3 \%$. Suksuwan et al. [6] designed and fabricated a small pilot-scale bubbling fluidized bed gasifier. The diameter of the reactor is $20 \mathrm{~cm}$ and the total height of the reactor from the bottom end of the cone to the top is $160 \mathrm{~cm}$. The feedstock used was palm kernel cake, which a size range of 1-10 mm. For the syngas, production study at the ER of 0.06 and 1.43 could not run continuously. Moreover, the gasification run at $E R=0.03$ and 2.64 was found that the syngas production was incombustible. Cardoso et al. [7] improved numerical approaches to predict hydrodynamics in a pilot-scale bubbling fluidized bed biomass reactor. Model validation was achieved by comparison to experimental results from a pilot-scale fluidized bed gathered at different temperatures. Smaller biomass particles revealed a uniform mixing, as a result of being close to the quartz sand particle size. Besides, it was found that increased superficial gas velocity improved binary mixing. Xiong et al. [8] performed a parametric investigation on biomass gasification in a fluidized bed gasifier. In this study, the rice husk gasification process, in a bubbling fluidized bed gasifier, was investigated using a kinetic model that comprises with hydrodynamics model. The results revealed that changes in the bed diameter have a negligible effect on the gasifier performance. On the other hand, the increment of reactor temperature and bed height improves gasifier efficiency.

Based on the literature review, there is a significant lack in studying the effect of biomass fuel characteristics on a gasification performance. The main aim of this work is to theoretical studying the effect of biomass fuel type on the gasification performance in a fluidized bed. The results of the mathematical model were verified by comparing its results with the experimental results of similar works.

\section{Mathematical Modelling}

The theoretical hydrodynamic-kinetic model constructed by El-Shafay et al. [9] was used to generate the results used in this study. In the numerical model, Silica sand of particle diameter $0.6-0.8 \mathrm{~mm}$ and density of $2800 \mathrm{~kg} / \mathrm{m}^{3}$ was selected as the bed material. This model contains three sub-models namely the pyrolysis sub-model, hydrodynamic sub-model, and kinetic sub-model. This model able to predict the gasification process performance during fluidized bed gasifiers at different agents and different fuel types. The model inputs are the reactor geometry, equivalence ratio, gasification temperature, fluidization velocity, ultimate and proximate analysis of the fuel. Detailed inputs value are presented in Table 1. The pyrolysis sub-model is used to calculate the species concentrations at the beginning of gasification as the initial conditions used in the reactions kinetic sub-model solving.

The inputs to the pyrolysis sub-model are the ultimate analysis $(\mathrm{C} \%, \mathrm{H} \%, \mathrm{~S} \%, \mathrm{~N} \%$, and $\mathrm{O} \%$ ) and the proximate analysis (moisture content MC \%) of the biomass, depending on the fuel type.

TABLE 1

THEORETICAL MODEL PARAMETERS.

\begin{tabular}{|c|c|c|}
\hline Category & Parameter, Symbol, Unit & Performed values \\
\hline Agent Type: Air & Equivalence ratio, ER, -- & $0.2-0.5$ \\
\hline $\begin{array}{l}\text { Operating } \\
\text { Temperature }\end{array}$ & Temperature, $\mathrm{T},{ }^{\circ} \mathrm{C}$ & $600-921$ \\
\hline \multirow{2}{*}{$\begin{array}{l}\text { Hydrodynamic } \\
\text { Parameters }\end{array}$} & $\begin{array}{l}\text { Fluidization velocity, } \mathrm{u}_{\mathrm{o}} \text {, } \\
\mathrm{m} / \mathrm{s}\end{array}$ & $0.2-0.8$ \\
\hline & Bed material, $\rho_{\mathrm{s}}, \mathrm{kg} / \mathrm{m}^{3}$ & 2800 \\
\hline \multirow[b]{2}{*}{$\begin{array}{l}\text { Biomass Fuel } \\
\text { Characteristics }\end{array}$} & $\begin{array}{l}\text { Ultimate analysis }(\mathrm{C} \% \text {, } \\
\mathrm{H} \%, \mathrm{O} \%, \mathrm{~N} \%, \mathrm{~S} \%)\end{array}$ & \multirow{2}{*}{$\begin{array}{l}\text { Sawdust pellets, Napier } \\
\text { Grass, Portuguese Peach } \\
\text { Stone, Chinese Coal /rice } \\
\text { straw, solid waste wood, } \\
\text { rice straw, and olive } \\
\text { kernels. }\end{array}$} \\
\hline & $\begin{array}{l}\text { Proximate analysis } \\
\text { (volatile matter } \% \text {, ash } \% \text {, } \\
\text { moisture contents, and } \\
\text { heating value), } \mathrm{MJ} / \mathrm{kg}\end{array}$ & \\
\hline \multirow{2}{*}{$\begin{array}{l}\text { Reactor } \\
\text { Geometry }\end{array}$} & $\begin{array}{l}\text { Fluidized bed and } \\
\text { freeboard height, } \mathrm{z}, \mathrm{mm}\end{array}$ & 3500 \\
\hline & $\begin{array}{l}\text { Reactor inner diameter, D, } \\
\mathrm{mm}\end{array}$ & 105 \\
\hline
\end{tabular}


The hydrodynamic sub-model concerning studying the effect of hydrodynamic parameters such as fluidization velocity and bed particle size and bed density. From this submodel, it can be calculated the minimum fluidization velocity, expanded bed height, voidage fraction bubble velocity, and bubble diameters.

According to El-Shafay et al. [9], the reactor column is made of a cylindrical tube, $105 \mathrm{~mm}$ inner diameter, and 3500 $\mathrm{mm}$ in height, it consists of four flanged sections; each one has a particular function and can be easily replaced or modified. An adjustable speed electric motor drives a screw feeder. More details and a schematic diagram of the fluidized bed reactor, as shown in Figure 1.

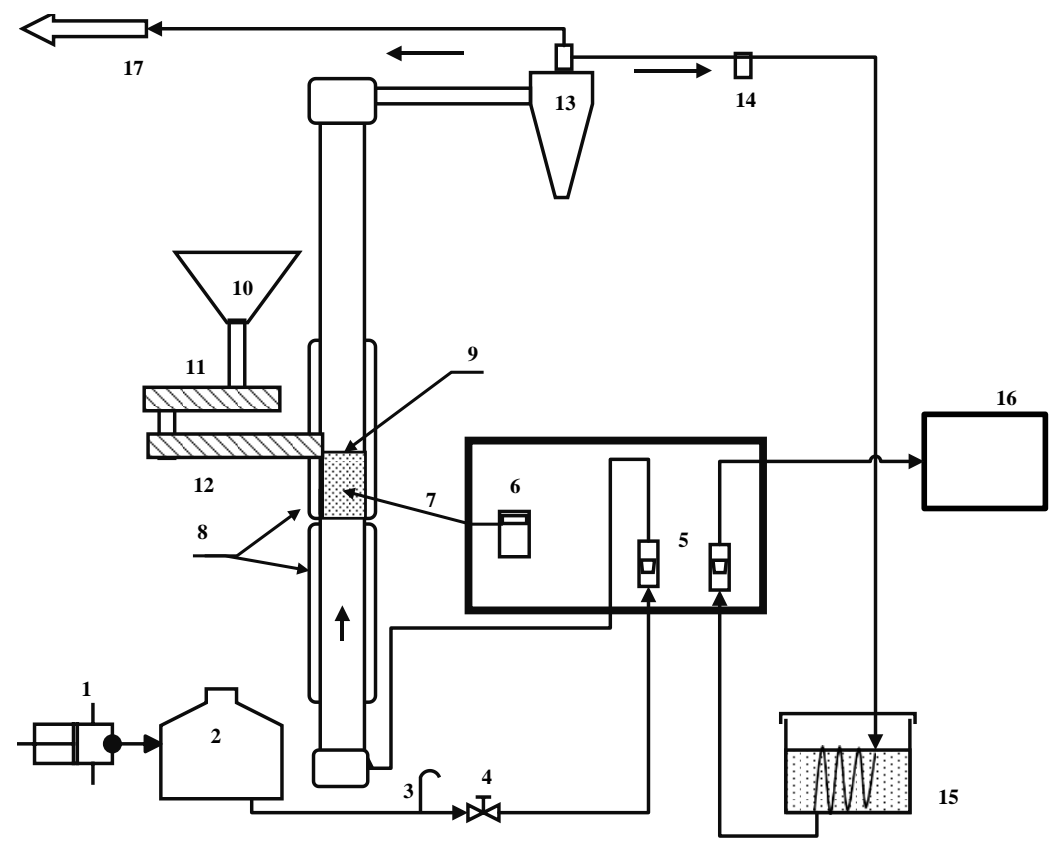

Fig. 1. The reactor schematic diagram.

1. Air compressor

2. Air accumulation tank

3. Air vent

4. Airflow valve

5. Rotameters

$\begin{array}{ll}6 & \begin{array}{l}\text { Power inverter and } \\ \text { temperature controller }\end{array} \\ 7 & \text { Thermocouple } \\ 8 & \text { Semi cylinder heaters } \\ 9 & \text { Fluidized bed } \\ 10 & \text { Hopper }\end{array}$

10 Hopper

$\begin{array}{llll}11 & \text { Upper fuel screw feeder } & 16 & \text { Syngas analyzer } \\ 12 & \text { Lower fuel screw feeder } & 17 & \text { Produced syngas } \\ 13 & \text { Cyclone } & & \\ 14 & \text { Primary fin filter } & & \\ 15 & \text { Ice bath } & & \end{array}$

$f_{b, j}=m_{f}\left(\frac{X_{j}}{M_{w j}}\right)$

$\mathrm{f}_{\mathrm{b}, \mathrm{j}}$ : The molar rate in the bubble phase, $(\mathrm{kmol} / \mathrm{s})$, and, $\mathrm{K}_{\mathrm{bc}}, \mathrm{K}_{\mathrm{ce}}$, and $\mathrm{K}_{\mathrm{be}}$ are the bubble/cloud, cloud/emulsion, and bubbles/emulsion mass transfer coefficients.

$\mathrm{C}_{\mathrm{j}}$ : Molar concentration, $\mathrm{kmol} / \mathrm{m}^{3}$

$\mathrm{u}_{\mathrm{B}}$ : Rise velocity of the bubble phase, $\mathrm{m} / \mathrm{s}$

$\mathrm{A}_{\text {bed }}$ : Bed cross-section area, $\mathrm{m}^{2}$

$\delta$ : Bed fraction consisting of bubbles, (--)

$\mathrm{H}_{\mathrm{eb}}$ : Expanded (bubbling) bed height, $\mathrm{m}$

$\mathrm{X}_{\mathrm{j}}$ : Mole fraction, (--)

$\mathrm{M}_{\mathrm{wj}}$ : Molecular weight, $\mathrm{kg} / \mathrm{kmol}$

$\frac{\mathrm{dC}_{\mathrm{b}, \mathrm{j}}}{\mathrm{dz}}=\frac{\mathrm{K}_{\mathrm{be}}}{\mathrm{u}_{\mathrm{B}}} \cdot\left(\mathrm{C}_{\mathrm{e}, \mathrm{j}}-\mathrm{C}_{\mathrm{b}, \mathrm{j}}\right)+\frac{\mathrm{R}_{\mathrm{b}, \mathrm{j}}}{\mathrm{u}_{\mathrm{B}}}+\frac{\mathrm{F}_{\mathrm{b}, \mathrm{j}}}{\mathrm{A}_{\mathrm{bed}} \cdot \mathrm{u}_{\mathrm{B}} \cdot \delta}$

$\mathrm{m}_{\mathrm{f}}$ : Fuel flow rate, $\mathrm{kg} / \mathrm{hr}$

The freeboard zone is situated over the dense bed zone, well mixing happens because of the behavior of the bubbles [10]. For the freeboard, the species balance equation can be written as follows [11]:
Where:

$\mathrm{F}_{\mathrm{b}, \mathrm{j}}=\left(\frac{4 \cdot \mathrm{f}_{\mathrm{b}, \mathrm{j}}}{\mathrm{H}_{\mathrm{eb}}^{4}}\right) \cdot \mathrm{z}^{3}$ 
$\frac{\mathrm{dC}_{\mathrm{fb}, \mathrm{j}}}{\mathrm{dz}}=\frac{\mathrm{R}_{\mathrm{fb}, \mathrm{j}}}{\mathrm{u}_{\mathrm{o}}}$

Where;

$\mathrm{u}_{\mathrm{o}}$ : Fluidization velocity, $\mathrm{m} / \mathrm{s}$

\subsection{Reaction mechanism of the kinetic sub-model}

The reaction mechanism of the kinetic sub-model was performed as Reaction Kinetics as a two-step kinetic mechanism. The process of gasification begins with pyrolysis, followed by combustion and steam gasification. The reactions involved in this process are as follows [12]:

A-Combustion reaction:

$\mathrm{C}+\frac{\lambda+2}{2(\lambda+2)} \mathrm{O}_{2} \stackrel{\mathrm{r}_{1}}{\longrightarrow} \frac{\lambda}{\lambda+1} \mathrm{C}+\frac{1}{\lambda+1} \mathrm{CO}_{2}$

where; $\lambda=1.5 \times 10^{6} \exp \left(\frac{30178}{\mathrm{~T}}\right)$

where; $\lambda$ is a mechanism factor

\section{B-Steam-Gasification reaction:}

$\mathrm{C}+\mathrm{H}_{2} \mathrm{O} \stackrel{\mathrm{r}_{2}}{\longrightarrow} \mathrm{CO}+\mathrm{H}_{2}$

$\mathrm{CO}+\mathrm{H}_{2} \mathrm{O} \stackrel{\mathrm{r}_{3}}{\longrightarrow} \mathrm{CO}_{2}+\mathrm{H}_{2}$

$\mathrm{C}+2 \mathrm{H}_{2} \mathrm{O} \stackrel{\mathrm{r}_{4}}{\longrightarrow} \mathrm{CO}_{2}+2 \mathrm{H}_{2}$

$\mathrm{C}+1.4 \mathrm{H}_{2} \mathrm{O} \stackrel{\mathrm{r}_{5}}{\longrightarrow} 0.4 \mathrm{CO}_{2}+0.6 \mathrm{CO}+1.4 \mathrm{H}_{2}$

The reaction rate equation for the above-mentioned combustion and steam gasification reactions can be defined as follows:

- The reaction rate for combustion reaction:

$\frac{\mathrm{dX}_{\mathrm{CO}}}{\mathrm{dt}}=\mathrm{k}_{\mathrm{CO}} \exp \left(-\frac{\mathrm{E}_{\mathrm{CO}}}{\mathrm{RT}}\right) \mathrm{P}_{\mathrm{O}_{2}}^{\mathrm{n}}\left(1-\mathrm{X}_{\mathrm{CO}}\right)^{2 / 3}$

- The reaction rate for steam gasification reaction:

$\frac{\mathrm{dX}_{\mathrm{SG}}}{\mathrm{dt}}=\mathrm{k}_{\mathrm{SG}} \exp \left(-\frac{\mathrm{E}_{\mathrm{SG}}}{\mathrm{RT}}\right) \mathrm{P}_{\mathrm{H}_{2} \mathrm{O}}^{\mathrm{n}}\left(1-\mathrm{X}_{\mathrm{SG}}\right)^{2 / 3}$

\subsection{Assumptions and initial conditions of the kinetic model}

\section{- Assumptions}

The assumptions of the kinetic sub-model are as following, [9].

1. Steady-state, one-dimensional model;

2. All gases are distributed uniformly in the emulsion phase;

3. The pyrolysis stage takes place suddenly, and the products are volatiles and char;

4. The outcomes of devolatilization are $\mathrm{C}, \mathrm{CO}, \mathrm{H}_{2}, \mathrm{CO}_{2}, \mathrm{H}_{2} \mathrm{O}$, $\mathrm{O}_{2}, \mathrm{CH}_{4}, \mathrm{~N}_{2}$, and tar;

5. Char particles are at a uniform and constant size spherically shaped; the char particles consist of only carbon (solid); and
6. The gasification of the char starts in the bed and is completed in the freeboard.

\section{- Initial conditions}

The pyrolysis of biomass particles occurred at the entry of the gasifier. The distribution of products is particularly sensitive to the heat rate of the reactor. The species concentrations released from the pyrolysis step can be considered as an initial condition for this model. Equations (14-22) in this sub-model are the correlations identified from the data presented by Mirmoshtaghi [13]. The inputs to the model are the ultimate analysis $(\mathrm{C}, \mathrm{H}$, and $\mathrm{O}(\%))$ and proximate analysis (moisture content (MC, \%)) of the biomass.

$$
\begin{aligned}
& \mathrm{C}_{\mathrm{C}}=\frac{1}{\mathrm{~A}_{\text {bed }} \times \mathrm{u}_{\mathrm{o}}}\left[0.144 \times \mathrm{C}_{\mathrm{ulti}} \times \frac{\mathrm{m}_{\mathrm{f}}(1-\mathrm{MC})}{\mathrm{M}_{\mathrm{w}, \mathrm{C}}}\right] \mathrm{kmol} / \mathrm{m}^{3} \\
& \mathrm{C}_{\mathrm{CO}}=\frac{1}{\mathrm{~A}_{\mathrm{bed}} \times \mathrm{u}_{\mathrm{o}}}\left[0.1474 \times \mathrm{C}_{\mathrm{ulti}}+0.2175 \times \mathrm{O}_{\mathrm{ulti}}\right] \times \frac{\mathrm{m}_{\mathrm{f}}(1-\mathrm{MC})}{\mathrm{M}_{\mathrm{w}, \mathrm{CO}}} \\
& \mathrm{C}_{\mathrm{CO}_{2}}=\frac{1}{\mathrm{~A}_{\text {bed } \times \mathrm{u}_{\mathrm{o}}}}\left[0.03434 \times \mathrm{C}_{\mathrm{ulti}}+0.09865 \times \mathrm{O}_{\mathrm{ulti}}\right] \times \frac{\mathrm{m}_{\mathrm{f}}(1-\mathrm{MC})}{\mathrm{M}_{\mathrm{w}, \mathrm{CO}_{2}}} \\
& \mathrm{C}_{\mathrm{H}_{2} \mathrm{O}}=\left[0.000983 \times \mathrm{H}_{\mathrm{ulti}}+0.00101 \times \mathrm{O}_{\mathrm{ulti}}+\mathrm{MC}\right] \\
& \times \frac{m_{f}(1-M C)}{A_{\text {bed }} \times u_{\mathrm{o}} \times M_{w, H_{2}} \mathrm{O}} \\
& \mathrm{C}_{\mathrm{H}_{2}}=\frac{1}{\mathrm{~A}_{\text {bed }} \times \mathrm{u}_{\mathrm{o}}}\left[0.032787 \times \mathrm{H}_{\mathrm{ulti}}\right] \times \frac{\mathrm{m}_{\mathrm{f}}(1-\mathrm{MC})}{\mathrm{M}_{\mathrm{w}, \mathrm{H}_{2}}} \\
& \mathrm{C}_{\mathrm{CH}_{4}}=\frac{1}{\mathrm{~A}_{\mathrm{bed}} \times \mathrm{u}_{\mathrm{o}}}\left[0.066 \times \mathrm{C}_{\mathrm{ulti}}+0.154 \times \mathrm{O}_{\mathrm{ulti}}\right] \times \frac{\mathrm{m}_{\mathrm{f}}(1-\mathrm{MC})}{\mathrm{M}_{\mathrm{w}, \mathrm{CH}_{4}}} \\
& \mathrm{C}_{\mathrm{O}_{2}}=\frac{1}{\mathrm{~A}_{\text {bed }} \times \mathrm{u}_{\mathrm{o}}}[0.00481 \times \mathrm{ER}] \\
& \mathrm{C}_{\mathrm{N}_{2}}=\frac{1}{\mathrm{~A}_{\text {bed }} \times \mathrm{u}_{\mathrm{o}}}[0.00181 \times \mathrm{ER}] \\
& \mathrm{C}_{\text {tar }}=\left[0.0606 \times \mathrm{C}_{\text {ulti }}+0.0819 \times \mathrm{H}_{\text {ulti }}+0.056 \times \mathrm{O}_{\text {ulti }}\right] \\
& \times \frac{m_{f}(1-M C)}{A_{\text {bed }} \times u_{o} \times M_{w, t a r}}
\end{aligned}
$$

\subsection{The model discretization and solution procedure}

\section{A. Discretization of the numerical solution}

The discretization of the numerical solution to test the solution sequence using fourth-order Dormand-Prince RungeKutta with adaptive step size as in the following section.

If $\mathrm{y}=\mathrm{f}(\mathrm{z}, \mathrm{y})$ and $\mathrm{y}^{\prime}=\mathrm{f}(\mathrm{z}, \mathrm{y})$ with an initial value of $\mathrm{y}\left(\mathrm{z}_{\mathrm{o}}\right)=\alpha \mathrm{z} ; z$ is the bed height, and $\alpha$ is the initial value. Define $\mathrm{z}_{\mathrm{n}+1}=\mathrm{z}_{\mathrm{n}}+\mathrm{n} \times \mathrm{h} ; h$ is the step numbers. $\mathrm{y}_{\mathrm{n}+1}=\left[\mathrm{C}_{\mathrm{e}, \mathrm{n}+1} \mathrm{C}_{\mathrm{b}, \mathrm{n}+1}\right]$ is the approximate solution resulting from Euler's method. And $\mathrm{w}_{\mathrm{n}+1}=\left[\mathrm{C}_{\mathrm{e}, \mathrm{n}+1} \mathrm{C}_{\mathrm{b}, \mathrm{n}+1}\right]$ is the approximate solution resulting from Heun's approach, where $\mathrm{C}_{\mathrm{e}, \mathrm{n}+1}$ and $\mathrm{C}_{\mathrm{b}, \mathrm{n}+1}$ are the concentrations of species $n$ in emulsion and bubble phase, respectively. Thus, we have two approximations, then the approximate error is $\left|\mathrm{w}_{\mathrm{n}+1}-\mathrm{y}_{\mathrm{n}+1}\right|$. The general explicit Dormand-Prince Runge-Kutta method is of the form $[14,15]$ : 


$$
\begin{aligned}
& \mathrm{y}_{\mathrm{n}+1}=\mathrm{y}_{\mathrm{n}}+\mathrm{h}\left(\frac{35}{384} \mathrm{k}_{1}+\frac{500}{1113} \mathrm{k}_{3}+\frac{125}{192} \mathrm{k}_{4}-\frac{2187}{6784} \mathrm{k}_{5}+\frac{11}{84} \mathrm{k}_{6}\right) \\
& \mathrm{w}_{\mathrm{n}+1}=\mathrm{w}_{\mathrm{n}}+\mathrm{h}\left(\begin{array}{l}
\frac{5179}{57600} \mathrm{k}_{1}+\frac{7571}{116695} \mathrm{k}_{3}+\frac{393}{640} \mathrm{k}_{4} \\
-\frac{92097}{339200} \mathrm{k}_{5}+\frac{187}{2100} \mathrm{k}_{6}+\frac{1}{40} \mathrm{k}_{7}
\end{array}\right) \\
& \left|\mathrm{w}_{\mathrm{n}+1}-\mathrm{y}_{\mathrm{n}+1}\right|=\mathrm{h}\left|\begin{array}{c}
\frac{71}{57600} \mathrm{k}_{1}-\frac{71}{16695} \mathrm{k}_{3}+\frac{71}{1920} \mathrm{k}_{4} \\
-\frac{17253}{339200} \mathrm{k}_{5}+\frac{22}{525} \mathrm{k}_{6}-\frac{1}{40} \mathrm{k}_{7}
\end{array}\right| \\
& \text { and } \mathrm{s}=\left(\frac{\mathrm{h} \times \text { tolerance }}{2\left|\mathrm{w}_{\mathrm{n}+1}-\mathrm{y}_{\mathrm{n}+1}\right|}\right)^{1 / 5}
\end{aligned}
$$

where $s$ is a factor used to control the step size. It depends on the tolerance and an approximate error, $h=s^{*} h$.

By assuming that, $k_{1}, k_{2}, k_{3}, k_{4}, k_{5}, k_{6}$, and $k_{7}$ are known as stages of the Dormand-Prince Runge-Kutta method and can be calculated from the following formulas [15].

$$
\begin{aligned}
& \mathrm{k}_{1}=\mathrm{h} \times \mathrm{f}\left(\mathrm{z}_{\mathrm{n}}, \mathrm{y}_{\mathrm{n}}\right) \\
& \mathrm{k}_{2}=\mathrm{h} \times \mathrm{f}\left(\mathrm{z}_{\mathrm{n}}+\frac{1}{5} \mathrm{~h}, \mathrm{y}_{\mathrm{n}}+\frac{1}{5} \mathrm{k}_{1}\right) \\
& \mathrm{k}_{3}=\mathrm{h} \times \mathrm{f}\left(\mathrm{z}_{\mathrm{n}}+\frac{3}{10} \mathrm{~h}, \mathrm{y}_{\mathrm{n}}+\frac{3}{40} \mathrm{k}_{1}+\frac{9}{40} \mathrm{k}_{2}\right) \\
& \mathrm{k}_{4}=\mathrm{h} \times \mathrm{f}\left(\mathrm{z}_{\mathrm{n}}+\frac{4}{5} \mathrm{~h}, \mathrm{y}_{\mathrm{n}}+\frac{44}{45} \mathrm{k}_{1}-\frac{56}{15} \mathrm{k}_{2}+\frac{32}{9} \mathrm{k}_{3}\right) \\
& k_{5}=h \times f\left(\begin{array}{l}
z_{n}+\frac{8}{9} h, y_{n}+\frac{19372}{6561} k_{1} \\
-\frac{25360}{2187} k_{2}+\frac{64448}{6561} k_{3}-\frac{212}{729} k_{4}
\end{array}\right) \\
& \mathrm{k}_{6}=\mathrm{h} \times \mathrm{f}\left(\begin{array}{c}
\mathrm{z}_{\mathrm{n}}+\mathrm{h}, \mathrm{y}_{\mathrm{n}}+\frac{9017}{3168} \mathrm{k}_{1}-\frac{355}{33} \mathrm{k}_{2} \\
-\frac{46732}{5247} \mathrm{k}_{3}+\frac{49}{176} \mathrm{k}_{4}-\frac{5103}{18656} \mathrm{k}_{5}
\end{array}\right) \\
& \mathrm{k}_{7}=\mathrm{h} \times \mathrm{f}\left(\begin{array}{c}
\mathrm{z}_{\mathrm{n}}+\mathrm{h}, \mathrm{y}_{\mathrm{n}}+\frac{35}{384} \mathrm{k}_{1}+\frac{500}{1113} \mathrm{k}_{3} \\
+\frac{125}{192} \mathrm{k}_{4}-\frac{2187}{6784} \mathrm{k}_{5}+\frac{11}{84} \mathrm{k}_{6}
\end{array}\right)
\end{aligned}
$$

\section{B. Numerical solution procedure}

The mass balance differential Eqs. (1), (2), and (5) have been solved numerically based on the Dormand-Prince RungeKutta 45 integration method using MATLAB 2016a code [14]. The adaptive step-size method using ode45 solver was used in the Matlab code, this is due to the rapid growth of species concentration in the emulsion phase near the bed bottom. The kinetic sub-model calculates the species concentrations in both the emulsion and bubble phase from Eqs. (1), (2), and (5) through a system of ODEs. Then, the ODEs system was solved at each reactor height step $(z)$, to calculate the average species concentration. These equations were solved starting from the distributor $(z=0)$ to the end of the reactor $(z=2.5)$. The key steps to solving the above equations for each cell are described below:

(1) Set the operating conditions (gasification temperature, equivalence ratio, fluidization velocity, sand particle size, fuel ultimate, and proximate analysis). Table 1 shows the list of variables of the Matlab code.

(2) From the ultimate fuel analysis and the agent flow rate, calculate the initial conditions to calculate the concentrations in the first cell.

(3) From the hydrodynamic sub-model, calculate the expanded bed height, bubble velocity, bubble diameter, minimum fluidization velocity, void fraction, and the fraction of the bubble phase in a fluidized bed.

(4) Set the z-axis span in both of fluidized bed and the freeboard zone and set the ode 45 options (error tolerance and maximum step size).

(5) Call ode45 solver to solve nine ordinary differential equations in bubble and emulsion phase in both of the fluidized bed and freeboard zone to calculate the species concentration at each $z$ (each cell outlet).

(6) During the calculation, each reaction rate and the mole fractions of the reactants involved in the heterogeneous reactions were calculated.

(7) If the difference of the species concentrations between current and old cell meets prescribed error tolerance, start the calculations of the next cell. Otherwise, go back to step (4) to decrease the step size and repeat the procedures.

\section{FEEDSTOCK SPECIFICATIONS}

In the case using sawdust fuel, the bed material is silica sand with a particle diameter of $600 \mu \mathrm{m}$ and a density of $2800 \mathrm{~kg} / \mathrm{m}^{3}$. In this work, the fuel specifications of several types of biomass fuels were inserted into the theoretical model, to studying the effect of fuel specifications and operating parameters on gasification performance. The current study was carried out on the sawdust pellets, Napier Grass, Portuguese Peach Stone, Chinese Coal /rice straw, solid waste wood, rice straw, and olive kernels.

The characteristics of the biomass are influenced by the origin of the biomass, but also by the entire supply system preceding any conversion step. The most important fuel properties, which give the first impression of a certain fuel, are given by proximate and ultimate analysis, heating value, and ash contents. The proximate analysis gives a fixed carbon, moisture contents, volatile matter, and ash content in the fuel. Also, the ultimate analysis provides the elemental atomic percentages of $\mathrm{C}, \mathrm{H}, \mathrm{O}, \mathrm{N}$, and $\mathrm{S}$.

Table 2 and Table 3 show the ultimate and proximate analysis of the sawdust pellets, Napier Grass, Portuguese Peach Stone, Chinese Coal /rice straw, solid waste wood, rice straw, and olive kernels. The proximate and ultimate analysis values fluctuate in a wide span, as is clear from Table 2 and Table 3 .

The olive kernels have higher moisture contents, volatile matters, and $\mathrm{N}$ atomic percentage than other feedstock. While the rice straw has higher ash contents. Napier grass and Chinese coal have higher oxygen contents and fixed carbon, 
respectively. Therefore, by comparing the sawdust analysis with other feedstock, the sawdust fuel has balancing proximate and ultimate analysis.

For the biomass fuel, the atomic ratio is established on the oxygen and hydrogen, and carbon content of the biomass fuel. Biomass fuel has considerably higher ratios of $\mathrm{H} / \mathrm{C}$ and $\mathrm{O} / \mathrm{C}$ than fossil fuels.

TABLE 2

BiOMASS UlTiMATE FUEL ANALYSIS.

\begin{tabular}{|c|c|c|c|c|c|c|}
\hline \multirow[b]{2}{*}{ Feedstock } & \multicolumn{6}{|c|}{ Ultimate Analysis (\%wt.) } \\
\hline & $\mathrm{C}$ & $\mathrm{H}$ & $\mathrm{O}$ & $\mathrm{N}$ & $S$ & $\begin{array}{c}\text { Atomic Ratio } \\
\text { (H/C), } \\
\text { Calculated }\end{array}$ \\
\hline $\begin{array}{l}\text { Sawdust } \\
\text { Pellets [9] }\end{array}$ & 47.37 & 6.3 & 42 & 0.12 & 0.08 & \\
\hline $\begin{array}{l}\text { Napier } \\
\text { Grass [16] }\end{array}$ & 45.1 & 5.94 & 48.52 & 0.45 & 0.00 & 1.753 \\
\hline $\begin{array}{l}\text { Portuguese } \\
\text { Peach } \\
\text { Stone [17] }\end{array}$ & 41.00 & 5.70 & 48.40 & 4.90 & 0.00 & 2.022 \\
\hline $\begin{array}{l}\text { Chinese } \\
\text { Coal [2] }\end{array}$ & 70.35 & 4.56 & 10.53 & 1.04 & 0.55 & 2.167 \\
\hline $\begin{array}{l}\text { Rice Straw } \\
{[15]}\end{array}$ & 38.61 & 4.28 & 37.16 & 1.08 & 0.65 & 0.718 \\
\hline $\begin{array}{l}\text { Solid waste } \\
\text { wood [5] }\end{array}$ & 49.8 & 6.1 & 33.9 & 0.2 & 0.98 & 1.860 \\
\hline $\begin{array}{l}\text { Rice straw } \\
\text { [4] }\end{array}$ & 40.83 & 4.91 & 31.26 & 1.14 & 0.52 & 1.462 \\
\hline $\begin{array}{l}\text { Olive } \\
\text { kernels [3] }\end{array}$ & 48.59 & 5.73 & 44.06 & 1.57 & 0.63 & 1.781 \\
\hline
\end{tabular}

TABLE 3

BIOMASS FUEL PROXIMATE ANALYSIS.

\begin{tabular}{|c|c|c|c|c|c|}
\hline & \multicolumn{4}{|c|}{ Proximate Analysis (\%wt.) } & \multirow{2}{*}{$\begin{array}{c}\text { Heating } \\
\text { Value } \\
(\mathrm{MJ} / \mathrm{kg})\end{array}$} \\
\hline & $\mathrm{MC}^{\mathrm{a}}$ & Ash & $\mathrm{VM}^{\mathrm{b}}$ & $\mathrm{FC}^{\mathrm{c}}$ & \\
\hline $\begin{array}{l}\text { Sawdust } \\
\text { Pellets [9] }\end{array}$ & 8.8 & 0.58 & 74.61 & 16.01 & 17.95 \\
\hline $\begin{array}{l}\text { Napier Grass } \\
{[16]}\end{array}$ & 4.64 & 6.31 & 85.52 & 8.17 & 16.73 \\
\hline $\begin{array}{l}\text { Portuguese } \\
\text { Peach Stone } \\
{[17]}\end{array}$ & 7.0 & 1.0 & 63.00 & 29.00 & 18.30 \\
\hline $\begin{array}{l}\text { Chinese Coal } \\
{[2]}\end{array}$ & 3.73 & 9.19 & 28.51 & 58.52 & 28,22 \\
\hline $\begin{array}{l}\text { Rice Straw } \\
{[15]}\end{array}$ & 5.58 & 12.64 & 64.55 & 16.55 & 14.40 \\
\hline $\begin{array}{l}\text { Solid waste } \\
\text { wood [5] }\end{array}$ & 7.30 & 1.1 & 82.6 & 16.3 & 18.60 \\
\hline Rice straw [4] & 5.30 & 13.73 & 59.6 & 18.74 & 13.90 \\
\hline $\begin{array}{l}\text { Olive kernels } \\
\text { [3] }\end{array}$ & 12.3 & 1.1 & 85.8 & 36.3 & 20.96 \\
\hline
\end{tabular}

${ }^{a}$ Moisture content; ${ }^{\mathrm{b}}$ Volatile Matter; ${ }^{\mathrm{c}}$ Fixed Carbon

The lower $\mathrm{H} / \mathrm{C}$ ratio gives greater heating value, as well as gives more concentrations of $\mathrm{CO}$ and $\mathrm{CO}_{2}$. The atomic ratio is estimated from the following equation [12]:

$(\mathrm{H} / \mathrm{C})=1.4125(\mathrm{O} / \mathrm{C})+0.5004$

The calculated $\mathrm{H} / \mathrm{C}$ ratio for all used feedstocks is calculated in Table 3.

\section{RESULTS AND DISCUSSION}

In the following section, the detailed effect of the equivalence ratio, operating temperature, and fuel specifications on the syngas composition are discussed in the case of using different biomass fuels.

\section{A. Effect of equivalence ratio on syngas composition}

Figure 2 shows the experimental and theoretical results of gas composition versus equivalence ratio at different temperatures, performed by El-Shafay et al. [9]. Generally, the ER strongly influences the type and quantities of gasification products. At the same temperature, a high degree of combustion occurs at high ER which supplies more air into the gasifier. As well as improves char burning to produce more $\mathrm{CO}_{2}$, and $\mathrm{CH}_{4}$ remains almost the same with increasing ER. Besides, at high ER, it is observed that the $\mathrm{CO}$ yields reduced and $\mathrm{H}_{2}$ increased until $\mathrm{ER}=0.35$ then decreased. This effect is due to the oxidation of $\mathrm{H}_{2}$ and $\mathrm{CO}$ to $\mathrm{H}_{2} \mathrm{O}$ and $\mathrm{CO}_{2}$, also due to more air dilutes, the product has led to reducing the $\mathrm{H}_{2}$ yield.

Another reason for the $\mathrm{H}_{2}$ concentration decrease; may be the low amount of char was available in the gasifier at high ER to produce $\mathrm{H}_{2}$ through a water gas shift reaction. As well as, a higher degree of oxidation reaction occurs and contributes to the increase in $\mathrm{CO}_{2}$ and a decrease in $\mathrm{CO}$ in the product.

The $\mathrm{CO}_{2}$ production consumes more amount of $\mathrm{O}_{2}$ than $\mathrm{CO}$, which explains why carbon dioxide is overgrowing at higher ER. With an increase in ER, a larger quantity of $\mathrm{O}_{2}$ entered the gasifier, which increased the degree of oxidation of biomass and available carbon. Also, the moisture contents affect the combustion reactions to generate more hydrogen and a higher volume flow rate of the produced syngas. The moisture content of the biomass feedstock varied in a wide range $(3.73 \%-12.3 \%)$. Moreover, the attendance of water in biomass fuel affects its pyrolysis performance and influences the main concentration composition (quality) of the syngas yield. The model results in the case of sawdust, explained the concentrations of the $\mathrm{H}_{2}, \mathrm{CO}, \mathrm{CO}_{2}$, and $\mathrm{CH}_{4}$ are $14.74 \%$, $10.26 \%$, $13.3 \%$, and $2.33 \%$, respectively. From the experimental results obtained by El-Shafay et al. [9], at the same temperature, the concentrations of the $\mathrm{H}_{2}, \mathrm{CO}, \mathrm{CO}_{2}$, and $\mathrm{CH}_{4}$ are $15.2 \%, 9.96 \%, 12.73 \%$, and $2.4 \%$, respectively. Comparing the results of the mathematical model with these experimental results, the error is within the range of $\pm 4.5 \%$.

Figure 3 shows the comparison of the model results with experimental results performed on olive kernels by Skoulou et al. [3]. The authors performed the experiments in a fluidized bed gasifier that has a $6 \mathrm{~cm}$ inner diameter and $1.4 \mathrm{~m}$ height. The tests were carried out on $750{ }^{\circ} \mathrm{C}, 800^{\circ} \mathrm{C}$, and $850{ }^{\circ} \mathrm{C}$ as well as equivalence ratios of $0.2,0.3$, and 0.4 . The bed material was quartz sand as $500 \mu \mathrm{m}-425 \mu \mathrm{m}$. The model results 
explain the concentrations of $\mathrm{CO}, \mathrm{CO}_{2}, \mathrm{CH}_{4}$, and $\mathrm{H}_{2}$, are $15.75 \%, 18.72 \%, 4.04 \%$, and $23.3 \%$, respectively. While the experimental results of the syngas concentrations conducted by Skoulou et al. [3] are $\mathrm{H}_{2}$ (23.5\%), $\mathrm{CO}(16 \%), \mathrm{CO}_{2}(19.5 \%)$, and $\mathrm{CH}_{4}(3.8 \%)$. The error between model results and experimental results within the range of $\pm 6.3 \%$.

The comparison of the model results by experimental results performed on Napier Grass by Khezri et al. [16] is represented in Figure 4. The authors performed the experiments in a fluidized bed gasifier that has a $5.4 \mathrm{~cm}$ inner diameter and $37 \mathrm{~cm}$ height. The tests were carried out at $800^{\circ} \mathrm{C}$, an equivalence ratio of $0.2,0.3$, and 0.4 . The bed material was sand. The model results explain the concentrations of $\mathrm{CO}, \mathrm{CO}_{2}, \mathrm{CH}_{4}$, and $\mathrm{H}_{2}$, are $6.83 \%, 14.7 \%$, $7.68 \%$, and $18.24 \%$, respectively. While the experimental results of the syngas concentrations conducted by Khezri et al. [16] are $\mathrm{CO}(16 \%), \mathrm{CO}_{2}(19.5 \%), \mathrm{CH}_{4}(3.8 \%)$, and $\mathrm{H}_{2}$ $(23.5 \%)$. The error between model results and experimental results is within a range of $\pm 5 \%$.

Figure 5 shows the comparison of the model results by experimental results performed on Portuguese Peach Stone by Monteiro et al. [17]. The authors performed the experiments in a fluidized bed gasifier that has a $0.5 \mathrm{~m}$ inner diameter and a $4.14 \mathrm{~m}$ height. The tests were carried out at $750{ }^{\circ} \mathrm{C}$, and $800{ }^{\circ} \mathrm{C}$, with an equivalence ratio of $0.2-0.37$. The bed material was calcium magnesium carbonate of $0.4 \mathrm{~mm}$ in size density of $2800 \mathrm{~kg} / \mathrm{m}^{3}$. The model results explain the concentrations of $\mathrm{CO}, \mathrm{CO}_{2}, \mathrm{CH}_{4}$, and $\mathrm{H}_{2}$, are $17.28 \%, 17.54 \%$, $3.89 \%$, and $12.97 \%$, respectively. While the experimental results of the syngas concentrations conducted by Khezri et al. [16] are $\mathrm{CO}(18.2 \%), \mathrm{CO}_{2}(18 \%), \mathrm{CH}_{4}(4.1 \%)$, and $\mathrm{H}_{2}$ $(13.8 \%)$. The error between model results and experimental results is within the range of $\pm 7.9 \%$.

The comparison of the model results by experimental results performed on Chinese Coal/rice straw by Li et al. [2] is represented in Figure 6. The authors performed the experiments in a fluidized bed gasifier that has a $12 \mathrm{~cm}$ inner diameter and $1.578 \mathrm{~m}$ height. The tests were carried out on $921^{\circ} \mathrm{C}$, with an equivalence ratio of $0.26-0.42$. The model results explain the concentrations of $\mathrm{CO}, \mathrm{CO}_{2}, \mathrm{CH}_{4}$, and $\mathrm{H}_{2}$, are $33.16 \%, 17.93 \%, 2.57 \%$, and $20.64 \%$, respectively. While the experimental results of the syngas concentrations conducted by $\mathrm{Li}$ et al. [2] are $\mathrm{CO}(34.9 \%), \mathrm{CO}_{2}(20.1 \%), \mathrm{CH}_{4}$ (3.1\%), and $\mathrm{H}_{2}(21.96 \%)$. The error between model results and experimental results is within range $\pm 10.2 \%$. The error in the gas composition in the model results increases with temperature and some part of this error is due to the model simplification. On the other hand, measuring accuracy during experiments also contributed to increasing the relative error.

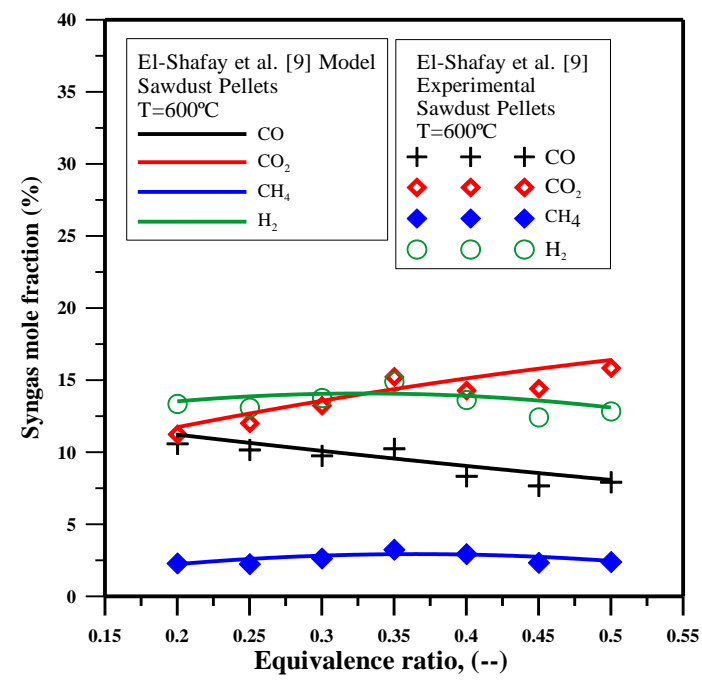

(a) $\mathrm{T}=600{ }^{\circ} \mathrm{C}$

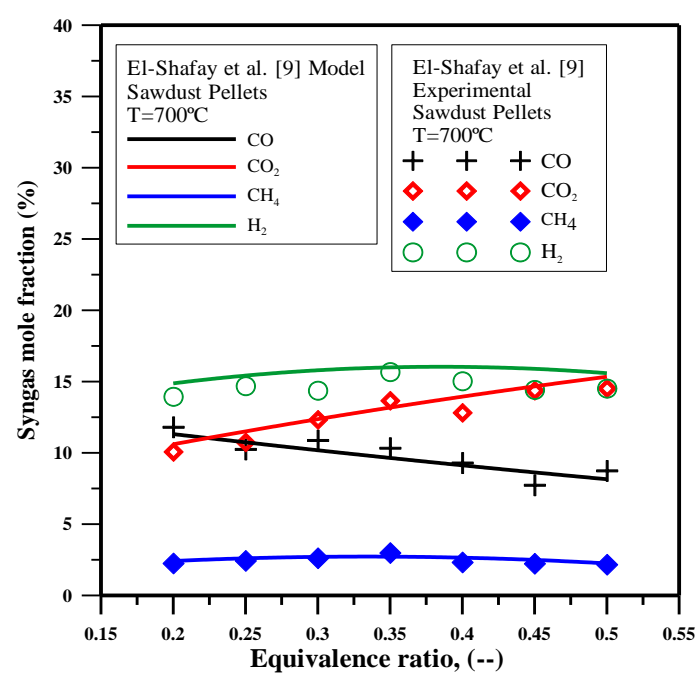

(b) $\mathrm{T}=700{ }^{\circ} \mathrm{C}$

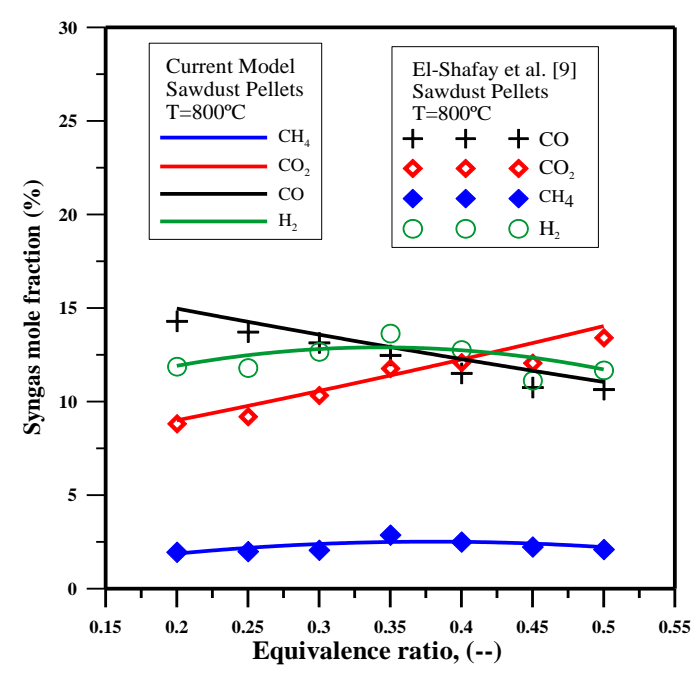

(c) $\mathrm{T}=800^{\circ} \mathrm{C}$ 


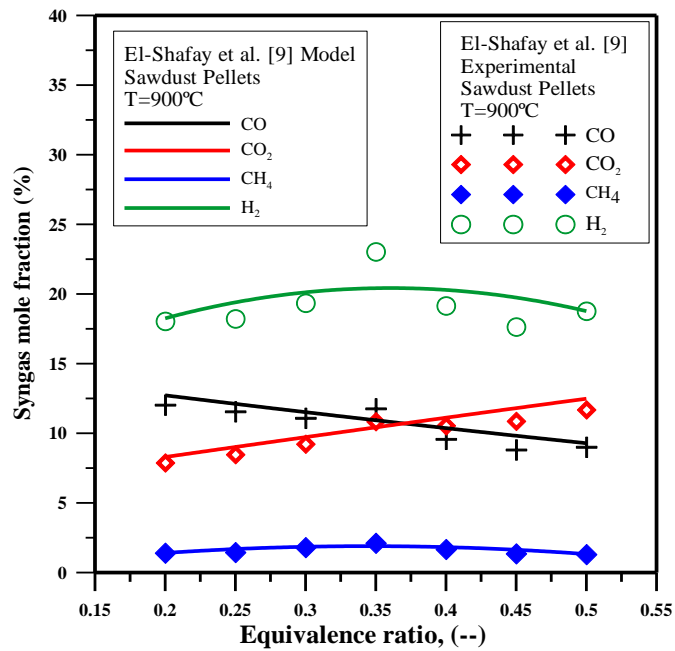

(d) $\mathrm{T}=900^{\circ} \mathrm{C}$

Fig. 2. Comparison of the model results with experimental results on sawdust pellets.

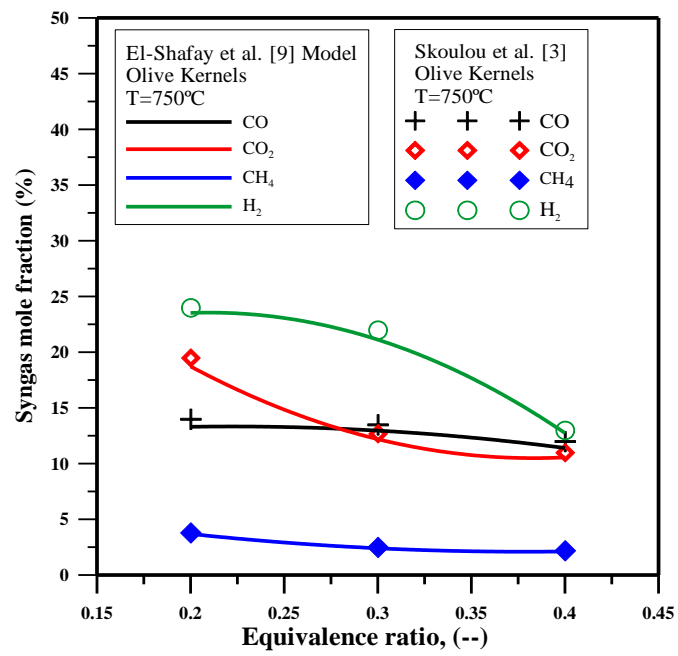

(a) $\mathrm{T}=750{ }^{\circ} \mathrm{C}$

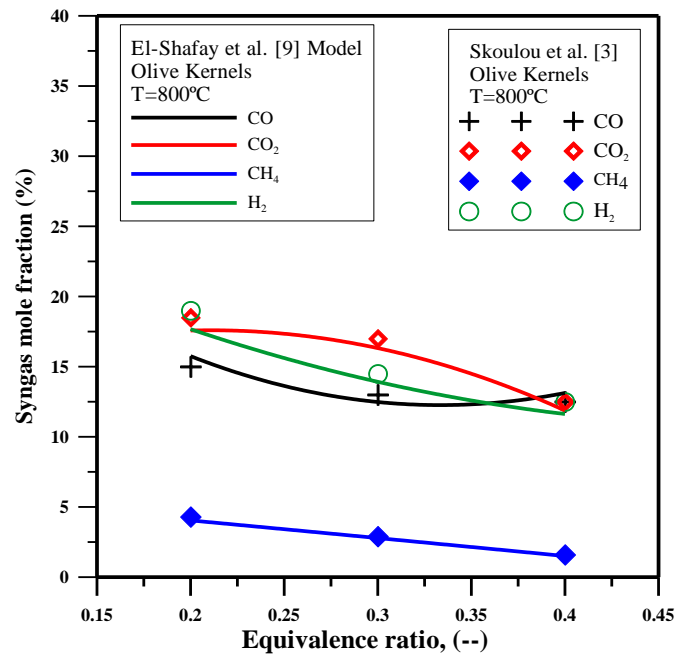

(b) $\mathrm{T}=800^{\circ} \mathrm{C}$

Fig. 3. Comparison of the model results with experimental results on olive kernels.

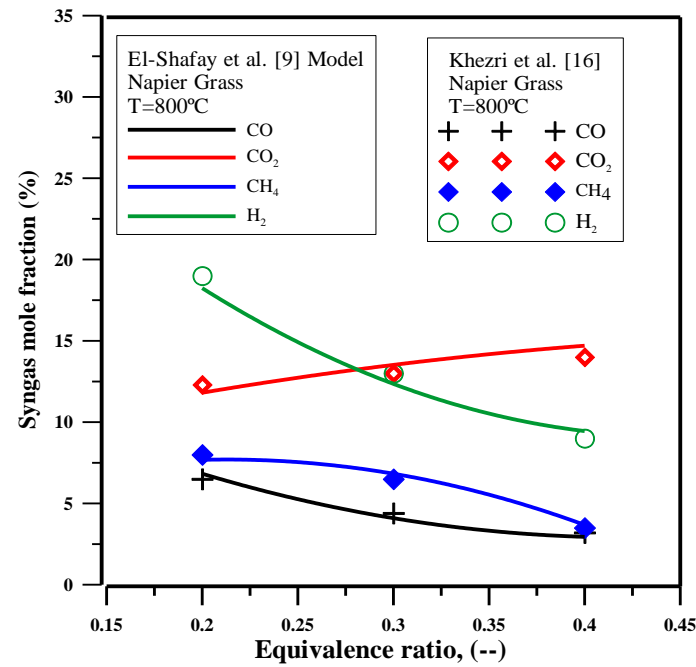

Fig. 4. Comparison of the model results with experimental results on Napier Grass.

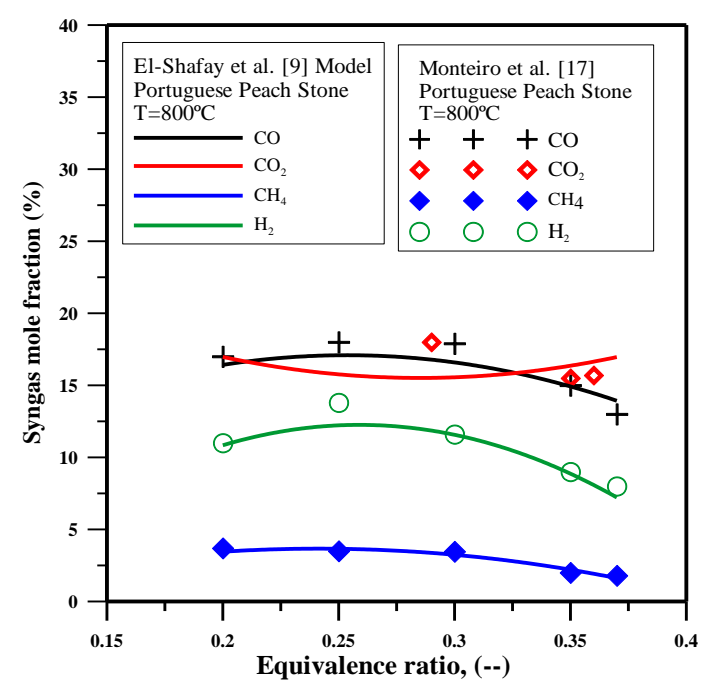

Fig. 5. Comparison of the model results with experimental results on Portuguese Peach Stone.

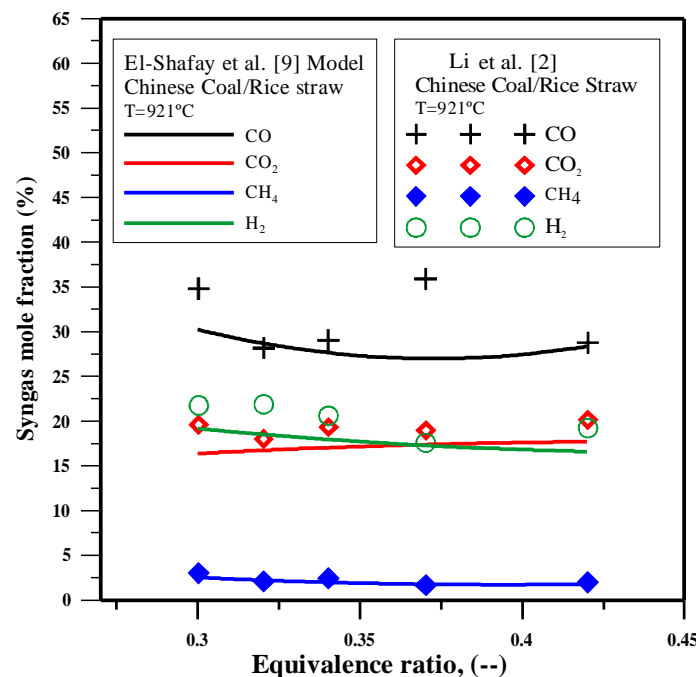

Fig. 6. Comparison of the model results with experimental results on Chinese Coal/rice straw. 


\section{B. Effect of operating temperature on syngas composition}

As it is clear from Figures 7 and 8, the combustible syngas composition increased with an increase in the operating temperature, this is due to the decreasing of char size at high temperatures. The moisture content of the biomass feedstock varied in a wide range $(3.73 \%-12.3 \%)$. The moisture contents affect the combustion reactions to generate more hydrogen and a higher volume flow rate of the produced syngas. The hydrogen yields in the case of using waste wood higher than their concentrations in the case of using rice straw. This is due to the higher moisture content in the case of waste wood $(7.3 \%)$ than rice straw $(5.58 \%)$. It is clear also from Table 2 that the $\mathrm{H} / \mathrm{C}$ ratio affects the $\mathrm{CO}$ yield. The biomass fuel that has a great moisture content (higher than 30\%) can cause some problems in the ignition process, and decrease the combustion temperature. Moreover, the attendance of water in biomass fuel affects its pyrolysis performance and influence the main concentration composition (quality) of the syngas yield. The $\mathrm{H} / \mathrm{C}$ ratios are 1.86 and 1.581 of rice straw and waste wood, respectively. These results can interpret the increase of $\mathrm{CO}$ concentrations in rice straw cases than in waste wood cases. The ash content in the biomass fuel is the inorganic incombustible portion in the fuel analysis. The ash contents are the mass that is left after the fuel was completely combusted. Table 2 shows the ash contents of the biomass fuel used in this study. The ash content varies within the range of $0.58 \%-13.73 \%$.

The ash softening temperature, sintering temperature, and melting temperature can fluctuate for different feedstock, and these temperatures are important during the controlling process on temperature to avoid slagging or sintering. Whatever, the higher temperature values led to a significant increase in incombustible gas concentrations and heating value. The melting point of ashes or the bed material restricts the maximum operating temperature of the reactor.

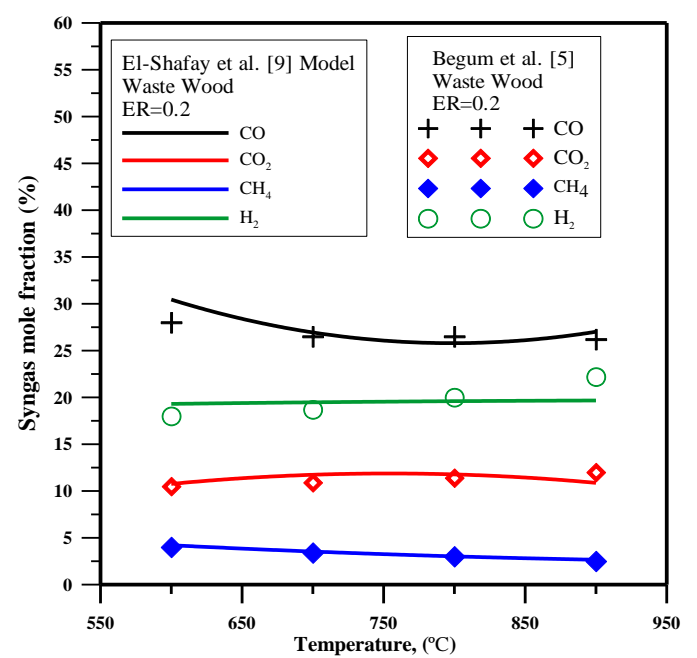

Fig. 7. Comparison of the model results with experimental results on waste wood.

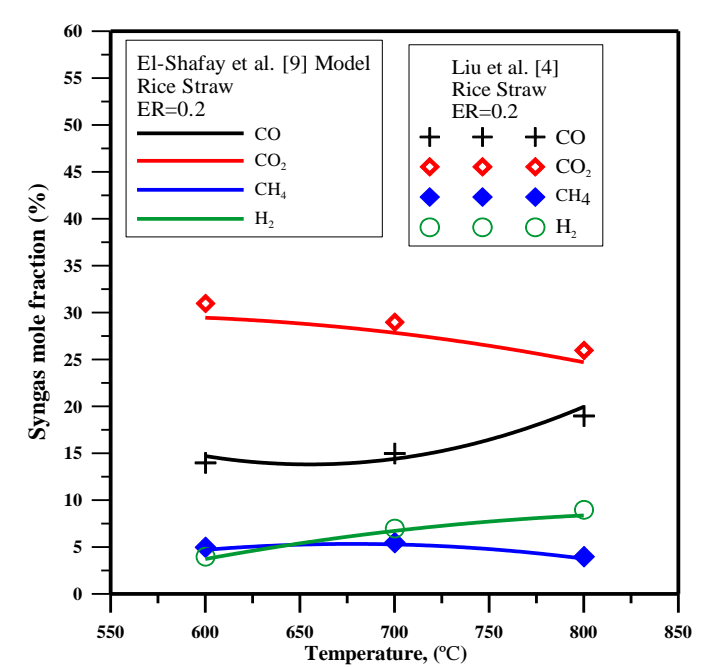

Fig. 8. Comparison of the model results with experimental results on rice straw.

\section{Effect of feedstock type on the syngas heating value}

The lower heating value (LHV) is calculated by deducting the energy desired to evaporate water that is made by the hydrogen and moisture content in the fuel. Coal fuel has a higher heating value compared to biomass. $\mathrm{H}$ and $\mathrm{C}$ atomic percentage in the fuel ultimate analysis incline to increase the fuel heating value, whereas the higher values of the oxygen atomic contents tend to decrease the LHV. The biomass feedstock has usually had a high volatile matter than other fossil fuels. Volatile matter is additionally divided into carbon monoxide, light hydrocarbons, hydrogen, carbon dioxide, tar, and moisture. The gas yields from the devolatilization of volatiles depend on the operating temperature and the fuel heating value. The quantity of gases devolatilized throughout the pyrolysis stage grows with growing the $\mathrm{H} / \mathrm{C}$ ratio and decreases as this ratio decrease. Therefore, the lower $\mathrm{H} / \mathrm{C}$ ratio gives a greater heating value.

Figures 9-12 show a comparison of the model results with experimental results performed on sawdust pellets, Olive kernels, Napier Grass, and Portuguese Peach Stone, respectively, versus the equivalence ratio. Figure 13 shows the comparison of the model results with experimental results of waste wood versus temperature. At lower values of equivalence ratio, the lower heating value of the producer syngas was slightly increased due to the increase of $\mathrm{H}_{2}$ and $\mathrm{CO}$ contents and decreases again at a higher equivalence ratio.

The results of the mathematical model of waste wood, sawdust pellets, Olive kernels, Napier Grass, and Portuguese Peach Stone, were compared with the experimental results achieved by several researchers under the same conditions. As well as, the highest value of the syngas heating value obtained from the model and experimental results, as well as the relative error of these results, are presented in Table 4. The chemical fuel characteristics were selected for these tests 
differ significantly. The energy content of the biomass fuels growing at higher moisture and oxygen content while the heating of syngas decreased. Olive kernels give more volatile matter, while the rice straw analysis shows the lower volatile matters and a higher amount of fixed carbon. These obvious variations in the fuel specifications lead to big variations in the gasification performance. In the case of using waste woody and rice straw, the significant increase of carbon monoxide (from $9 \%$ to $19 \%$ ) and carbon dioxide (from 25\% to $33.1 \%$ ) content in the syngas, can be attributed to the significant ratio of $\mathrm{C} / \mathrm{O}$ ratio in these biomasses analyses. As a result, the feedstock and its ultimate analysis and its contents from fixed carbons and volatiles matters affect strongly the producer gas concentrations, as a result, it is LHV.

The results are reported in Figs. 9-13, show that the LHV trend is consistent with that obtained for hydrogen, carbon monoxide, and methane due to their high heating values. Since waste wood gasification produced huge quantities of hydrocarbons, the LHV gradually increases up to $6.7 \mathrm{MJ} / \mathrm{Nm}^{3}$ at $\mathrm{ER}=0.3$ and $\mathrm{T}=900^{\circ} \mathrm{C}$. While the higher LHV that generated during olive kernels and rice straw gasification within the operating ranges is $5.9 \mathrm{MJ} / \mathrm{Nm}^{3}$ at $\mathrm{ER}=0.3$ and $\mathrm{T}=800{ }^{\circ} \mathrm{C}$ and $5.4 \mathrm{MJ} / \mathrm{Nm}^{3}$ at $\mathrm{ER}=0.3$ and $\mathrm{T}=900{ }^{\circ} \mathrm{C}$, respectively.

TABLE 4

COMPARISON OF LHV IN THE DIFFERENT FEEDSTOCKS.

\begin{tabular}{l||c||c||c}
\multicolumn{1}{c||}{ Feedstock } & \multicolumn{2}{c||}{$\begin{array}{c}\text { Highest Heating Value } \\
\left(\mathbf{M J} / \mathbf{N m}^{3}\right)\end{array}$} & $\begin{array}{c}\text { Error Range } \\
(\%)\end{array}$ \\
\cline { 2 - 3 } & Model & Experimental & \\
\hline Sawdust [9] & 4.51 & 4.59 & $\pm 1.7 \%$ \\
\hline Napier Grass [16] & 7 & 6.72 & $\pm 4.4 \%$ \\
\hline $\begin{array}{l}\text { Portuguese Peach } \\
\text { Stone [17] }\end{array}$ & 5.67 & 5.25 & $\pm 7.4 \%$ \\
\hline Waste wood [5] & 7.44 & 6.92 & $\pm 7.8 \%$ \\
\hline Rice straw [4] & 4.71 & 4.81 & $\pm 2.3 \%$ \\
\hline Olive kernels [3] & 5.67 & 5.73 & $\pm 2.1 \%$
\end{tabular}

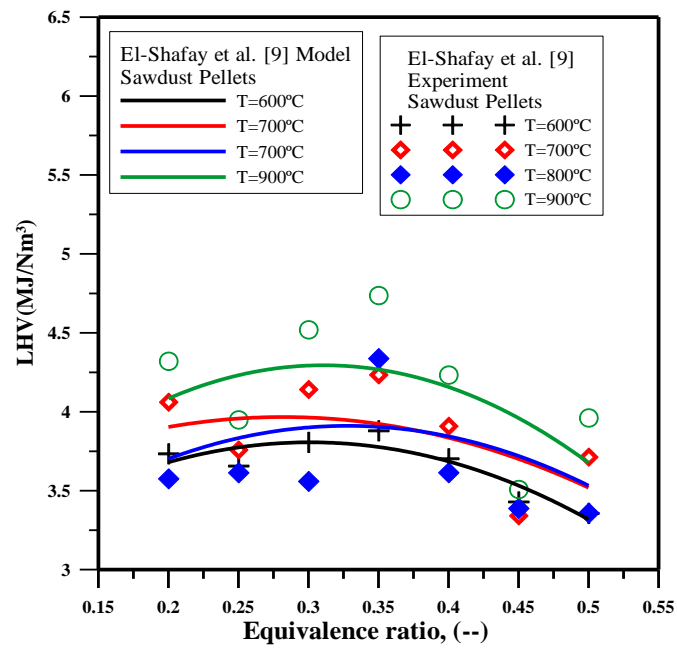

Fig. 9. Comparison of the model results with experimental results on sawdust pellets.

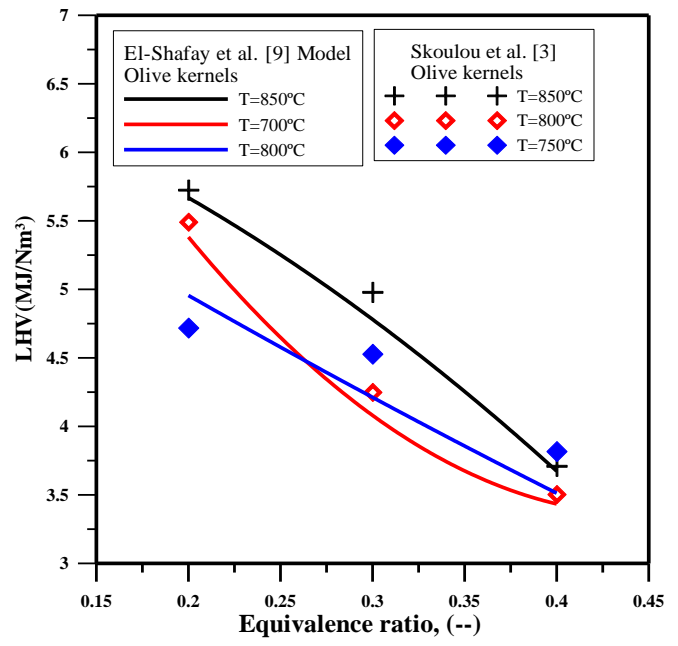

Fig. 10. Comparison of the model results with experimental results on Olive kernels.

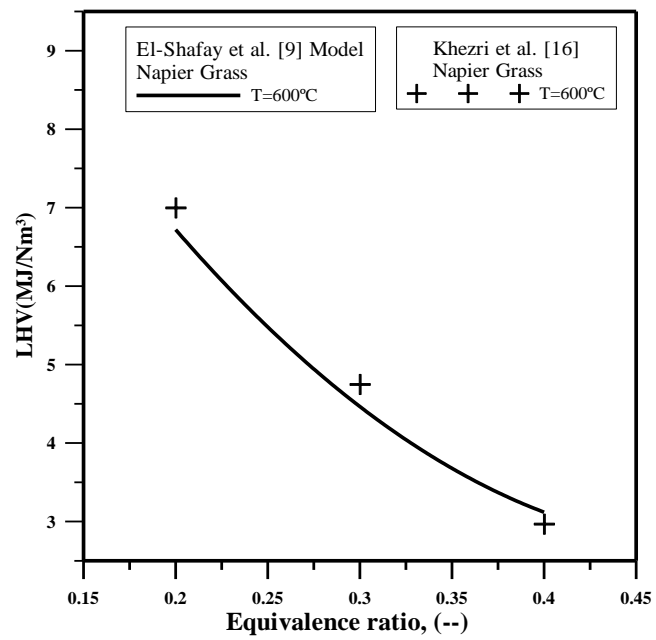

Fig. 11. Comparison of the model results with experimental results on Napier Grass.

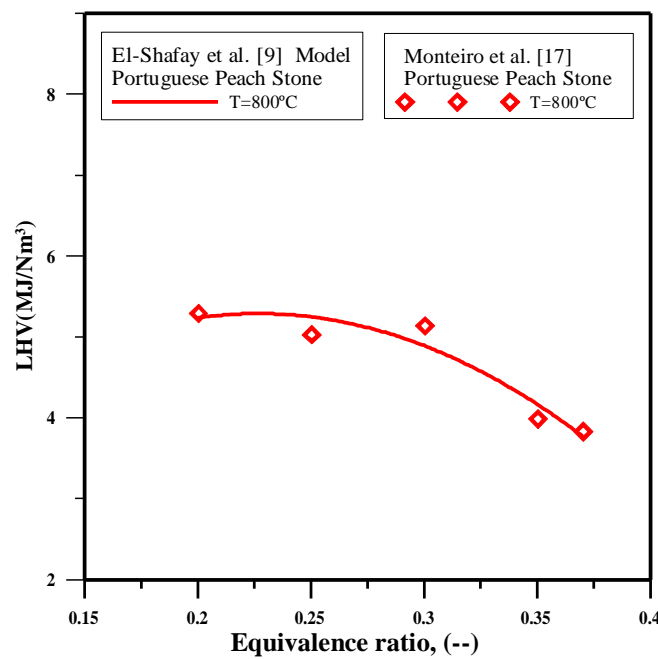

Fig. 12. Comparison of the model results with experimental results on Portuguese Peach Stone. 


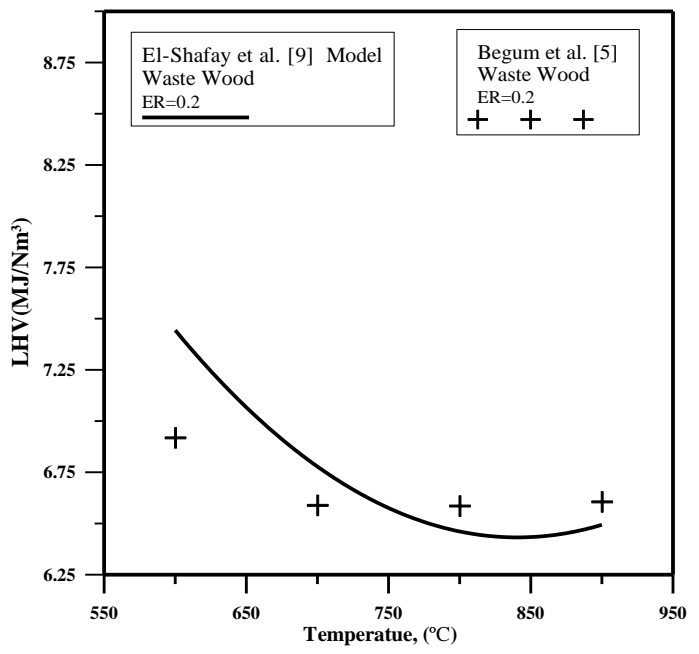

Fig. 13. Comparison of the model results with experimental results on waste wood.

\section{Effect of feedstock type on the cold gas efficiency}

The chemical energy of the fuel is converted to syngas, also known as cold gas efficiency. Figures 14 and 15 show the cold gas efficiency versus the equivalence ratio at different temperatures, in the case of using sawdust pellets and Chinese coal/rice straw, respectively. According to the results plotted in these figures, the produced syngas that generated during the gasification of sawdust pellets higher values of cold gas efficiency $\left(70.7 \%\right.$ at $\mathrm{ER}=0.3$ and $\left.\mathrm{T}=800^{\circ} \mathrm{C}\right)$. While the syngas obtained from the Chinese coal/rice straw gasification yields lower cold gas efficiency $\left(60.92 \%\right.$ at $\mathrm{ER}=0.3$ and $\left.\mathrm{T}=800{ }^{\circ} \mathrm{C}\right)$.

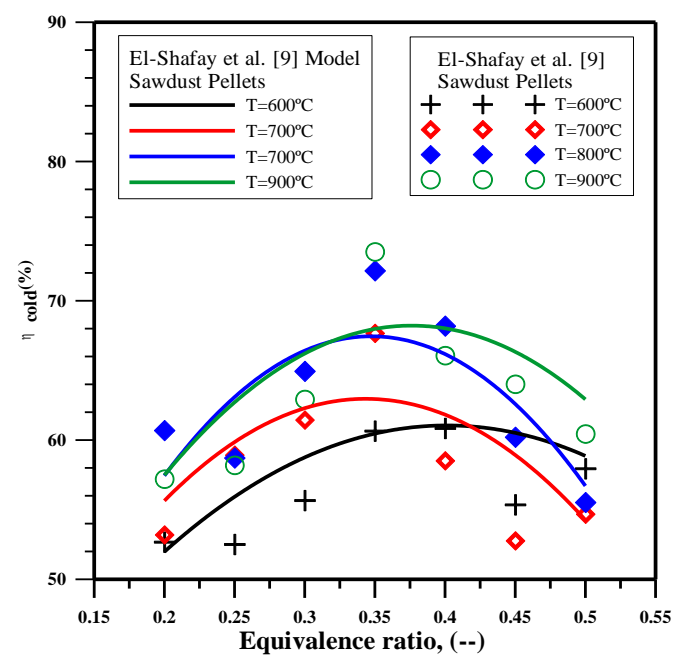

Fig. 14. Comparison of the model results with experimental results on sawdust pellets.

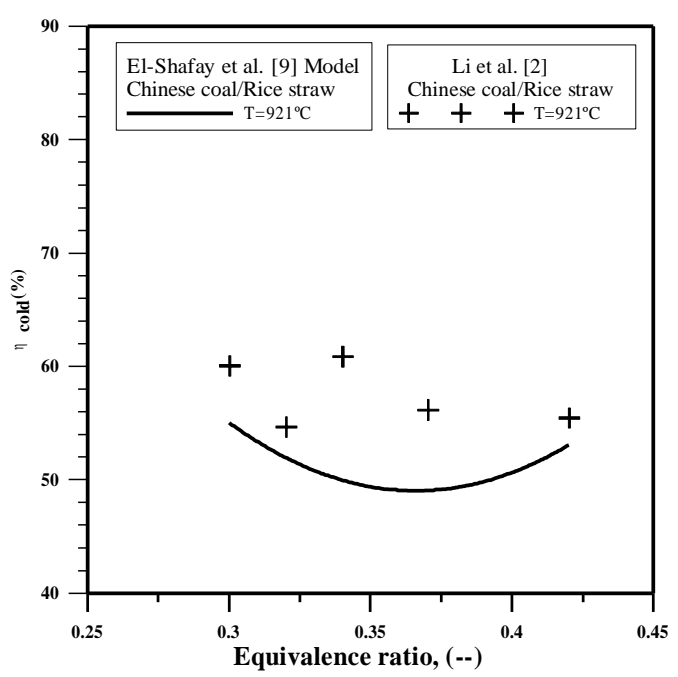

Fig. 15. Comparison of the model results with experimental results on Chinese/rice straw.

\section{Conclusions}

The study carried out a numerical evaluation of different biomass fuel gasification in a fluidized bed using air. The study was performed at a wide range of temperatures and equivalence ratios according to compare with published experimental results. The feedstocks used in this study were sawdust pellets, Napier Grass, Portuguese Peach Stone, Chinese Coal/rice straw, solid waste wood, rice straw, and olive kernels. Based on the comparison results of the theoretical results obtained from the kinetic-hydrodynamic and published experimental results, the main conclusions can be summarized as follows:

- Moisture contents motivate the combustion reaction series to generate more hydrogen.

- Higher values of the $\mathrm{H} / \mathrm{C}$ ratio give little heating value, as well as give lesser concentrations of $\mathrm{CO}$ and $\mathrm{CO}_{2}$.

- The fixed carbons and the volatile matter percentages in the ultimate analysis affect strongly the improvement of the combustible gas concentrations, as a result, it is LHV.

- The highest values of $\mathrm{CO}$ and $\mathrm{CH}_{4}$ are $33.16 \%$ of Chinese coal/rice straw at $\mathrm{ER}=0.2$ and $800{ }^{\circ} \mathrm{C}, 7.68 \%$ of Napier grass at $\mathrm{ER}=0.3$, and $800{ }^{\circ} \mathrm{C}$, respectively. While the highest concentrations of $\mathrm{CO}_{2}$ and $\mathrm{H}_{2}$ achieved of olive kernels are $18.72 \%$ at $\mathrm{ER}=0.4$ and $750{ }^{\circ} \mathrm{C}$ and $23.5 \%$ at $\mathrm{ER}=0.3$ and $850^{\circ} \mathrm{C}$, respectively.

- The solid waste wood is best among all the tested fuels in terms of cold gas efficiency, the maximum value of cold gas efficiency is $73.2 \%$ at $\mathrm{ER}=0.3$ and $800{ }^{\circ} \mathrm{C}$. The maximum value of LHV generated during solid waste wood gasification is $6.92 \mathrm{MJ} / \mathrm{Nm}^{3}$ at $\mathrm{ER}=0.3$ and $\mathrm{T}=850{ }^{\circ} \mathrm{C}$.

- The Chinese coal/rice straw gasification yields lower cold gas efficiency $\left(60.92 \%\right.$ at $\mathrm{ER}=0.3$ and $\left.\mathrm{T}=800{ }^{\circ} \mathrm{C}\right)$.

- The maximum relative error between model results and experimental results is within range $\pm 10.2 \%$. 


\section{THE AUTHOR CONTRIBUTIONS:}

A. S. El-Shafay

1. Data analysis and interpretation

2. Software

3. Drafting the article

4. Resources

A. A. Hegazi

1. Data collection and tools

\section{S. H. El-Emam}

1. Conception or design of the work

2. Critical revision of the article

\section{F. M. Okasha}

\section{Supervision}

\section{E. S. B. Zeidan}

1. Drafting the article

2. Investigation

3. Final approval of the version to be published

\section{NOMENCLATURE}

\begin{tabular}{|c|c|}
\hline Symbol & Description, unit \\
\hline$A_{\text {bed }}$ & Fluidized bed sectional area, $\mathrm{m}^{2}$ \\
\hline $\mathrm{C}_{\mathrm{b}}$ & Molar concentration in the bubble phase, $\mathrm{kmol} / \mathrm{m}^{3}$ \\
\hline $\mathrm{C}_{\mathrm{e}}$ & Molar concentration in the emulsion phase, $\mathrm{kmol} / \mathrm{m}^{3}$ \\
\hline $\mathrm{d}_{\mathrm{B}}$ & Bubble diameter, $\mathrm{m}$ \\
\hline$d_{p}$ & Particle diameter, $\mathrm{m}$ \\
\hline $\mathrm{D}$ & Reactor inner diameter, $\mathrm{m}$ \\
\hline ER & Equivalence ratio, (--) \\
\hline $\mathrm{h}$ & Step number, (--) \\
\hline $\mathrm{H}_{\mathrm{eb}}$ & Expanded (bubbling) bed height, $\mathrm{m}$ \\
\hline $\mathrm{k}$ & Equilibrium constant, $\mathrm{s}^{-1}$ \\
\hline $\mathrm{k}_{\mathrm{i}}$ & Stages of the Dormand-Prince Runge-Kutta method, (--) \\
\hline $\mathrm{K}_{\mathrm{be}}$ & Mass interchange coefficient between bubble and emulsion phase, $\mathrm{s}^{-1}$ \\
\hline LHV & Low heating value, $\mathrm{MJ} / \mathrm{Nm}^{3}$ \\
\hline $\mathrm{m}_{\mathrm{f}}$ & Fuel flow rate, $\mathrm{kg} / \mathrm{hr}$ \\
\hline $\mathrm{M}_{\mathrm{w}}$ & Molecular weight, $\mathrm{kg} / \mathrm{kmol}$ \\
\hline $\mathrm{MC}$ & Moisture contents, (--) \\
\hline $\mathrm{n}$ & Number of moles, kmol \\
\hline $\mathrm{P}_{\mathrm{O} 2}$ & Partial pressure of $\mathrm{O}_{2}, \mathrm{~Pa}$ \\
\hline $\mathrm{P}$ & Pressure, $\mathrm{Pa}$ \\
\hline $\mathrm{r}$ & Specific reaction rate, $\mathrm{kmol} / \mathrm{m}^{3} . \mathrm{s}$ \\
\hline $\mathrm{R}_{\mathrm{u}}$ & Universal gas constant, $\mathrm{kJ} / \mathrm{kmol} . \mathrm{K}$ \\
\hline $\mathrm{R}$ & Net reaction rate, $\mathrm{kmol} / \mathrm{m}^{3} . \mathrm{s}$ \\
\hline $\mathrm{s}$ & Factor used to control the step size, (--) \\
\hline $\mathrm{T}$ & Operating temperature, $\mathrm{K}$ \\
\hline $\mathrm{u}_{0}$ & Fluidization velocity, m/s \\
\hline $\mathrm{u}_{\mathrm{B}}$ & Rise velocity of the bubbles, $\mathrm{m} / \mathrm{s}$ \\
\hline $\mathrm{u}_{\mathrm{e}}$ & Rise velocity of particles, $\mathrm{m} / \mathrm{s}$ \\
\hline $\mathrm{u}_{\mathrm{mf}}$ & Minimum fluidization velocity, $\mathrm{m} / \mathrm{s}$ \\
\hline $\mathrm{X}$ & Mole fraction, (--) \\
\hline $\mathrm{y}$ & Mass fraction, function, (--) \\
\hline$\grave{y}$ & First differentiation of the function y, (--) \\
\hline $\mathrm{z}$ & Axial distance from air distributor, $\mathrm{m}$ \\
\hline
\end{tabular}

\section{Greek symbols}

\begin{tabular}{l||l}
$\alpha$ & Initial values, $\mathrm{kmol} / \mathrm{m}^{3}$ \\
\hline$\delta$ & Fraction of bed consisting of bubbles, (--) \\
\hline$\varepsilon_{\mathrm{mf}}$ & Bed voidage fraction at minimum fluidization, (--) \\
\hline$\eta_{\text {cold }}$ & Cold gas efficiency, (--) \\
\hline$\mu$ & Dynamic viscosity, N.s $/ \mathrm{m}^{2}$ \\
\hline$\rho_{\mathrm{g}}$ & Gas density, $\mathrm{kg} / \mathrm{m}^{3}$ \\
\hline$\rho_{\mathrm{s}}$ & Solid particles density, $\mathrm{kg} / \mathrm{m}^{3}$ \\
\hline$\Phi$ & Solid particles sphericity, (--)
\end{tabular}

\section{REFERENCES}

[1] C. Pfeifer, J. C. Schmid, T. Pröll, and H. Hofbauer, "Next Generation Biomass Gasifier," Proc. 19th Eur. Biomass Conf. Exhib., pp. 1-7, 2011.

[2] K. Li, R. Zhang, and J. Bi, "Experimental study on syngas production by co-gasification of coal and biomass in a fluidized bed," Int. J. Hydrogen Energy, vol. 35, no. 7, pp. 2722-2726, 2010.

[3] V. Skoulou, G. Koufodimos, Z. Samaras, and A. Zabaniotou, "Low temperature gasification of olive kernels in a $5-\mathrm{kW}$ fluidized bed reactor for H2-rich producer gas," Int. J. Hydrogen Energy, vol. 33, no. 22, pp. $6515-6524,2008$.

[4] L. Liu, Y. Huang, J. Cao, C. Liu, L. Dong, L. Xu, and J. Zha, "Experimental study of biomass gasification with oxygen-enriched air in fluidized bed gasifier," Sci. Total Environ., vol. 626, pp. 423-433, 2018.

[5] S. Begum, M. G. Rasul, and D. Akbar, "A numerical investigation of municipal solid waste gasification using aspen plus," Procedia Eng., vol. 90, pp. 710-717, 2014.

[6] W. Suksuwan, M. Wae, and M. Mel, "Development of mini pilot fluidized bed gasifier for industrial approach: Preliminary study based on continuous operation," J. Adv. Res. Fluid Mech. Therm. Sci., vol. 45, no. 1, pp. 35-43, 2018.

[7] J. Cardoso, V. Silva, D. Eusébio, P. Brito, and L. Tarelho, "Improved numerical approaches to predict hydrodynamics in a pilot-scale bubbling fluidized bed biomass reactor: A numerical study with experimental validation," Energy Convers. Manag., vol. 156, pp. 53-67, 2018.

[8] Q. Xiong, M. M. Yeganeh, E. Yaghoubi, A. Asadi, M. H. Doranehgard, and $\mathrm{K}$. Hong, "Parametric investigation on biomass gasification in a fluidized bed gasifier and conceptual design of gasifier," Chem. Eng. Process, vol. 127, pp. 271-291, 2018.

[9] A. S. El-Shafay, A. A. Hegazi, E. S. B. Zeidan, S. H. El-Emam, and F. M. Okasha, "Experimental and numerical study of sawdust airgasification," Alexandria Eng. J., vol. 59, no. 5, pp. 3665-3679, 2020.

[10] S. T. Pemberton and J. F. Davidson, "Turbulence in the freeboard bed of a gas-fluidised bed: The significance of ghost bubbles," Chem. Eng. Sci., vol. 39, no. 5, pp. 829-840, 1984.

[11] F. Okasha, "Modeling of liquid fuel combustion in fluidized bed," Fuel, vol. 86, no. 15, pp. 2241-2253, 2007.

[12] P. Basu. Biomass Gasification, and Pyrolysis: Practical Design and Theory, Academic Press in an imprint of Elsevier, 2010.

[13] G. Mirmoshtaghi, "Biomass gasification in fluidized bed gasifiers: Modeling and simulation," Ph.D. diss., Mälardalen University, 2016.

[14] R. P. Canale and S. C. Chapra. Numerical Methods for Engineers. Mathematics and Computers in Simulation, Boston: McGraw-Hill Higher Education, vol. 33, no. 3, p. 260, 2003.

[15] K. Zwarycz-Makles, and D. Majorkowska-Mech, "Gear and RungeKutta numerical discretization methods in differential equations of adsorption in adsorption heat pump," Applied Sciences, vol. 8, no. 12, p. 2437, 2018.

[16] R. Khezri, W. Azlinaa, and H. B. Tana, "An experimental investigation of syngas composition from small-scale biomass gasification," Int. J. Biomass Renewables, vol. 5, no. 1, pp. 6-13, 2016.

[17] E. Monteiro, T. M. Ismail, A. Ramos, M. A. El-Salam, P. Brito, and A. Rouboa, "Experimental and modeling studies of Portuguese peach stone gasification on an autothermal bubbling fluidized bed pilot plant," Energy, vol. 142, pp. 862-877, 2018.

Title Arabic:

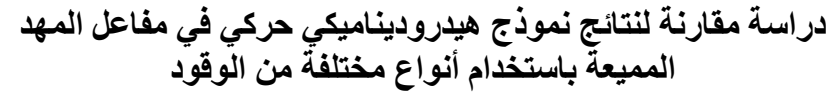




\section{Arabic Abstract:}

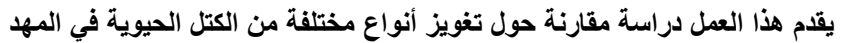

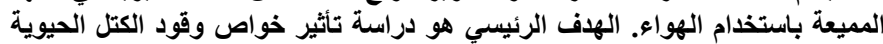

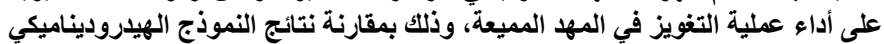

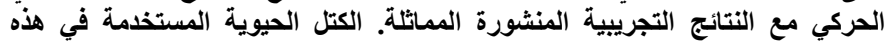

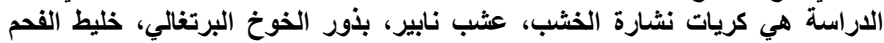

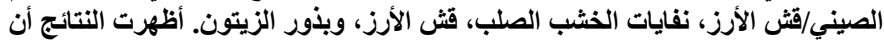

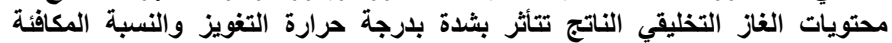

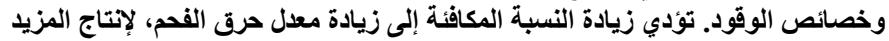

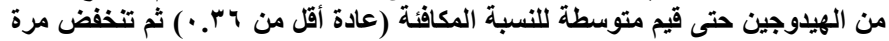
أخرى. زادت تركيزات الميثان و أول أكسيد الكربون و الهيدروجين بزيادة درجة الحرارة.
من التحليل التقريبي للوقود، تؤثُر كمية الرطوبة على تفاعلات الاحتراق لتنتج المزيد من

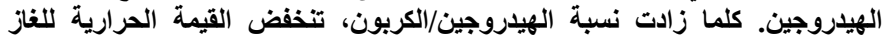

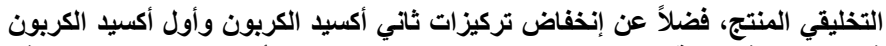

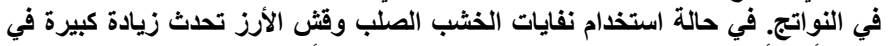

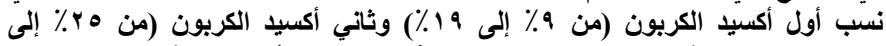

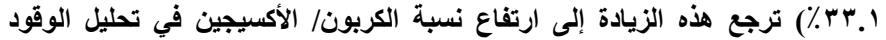

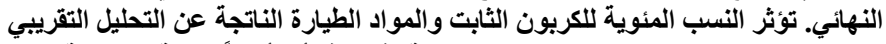

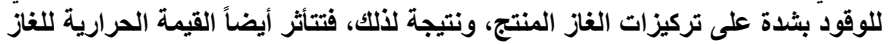

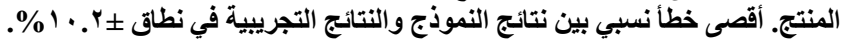

